\title{
Furanoflavones and other Chemical Constituents of Lonchocarpus obtusos
}

\author{
Maria Gilvânia B. Cavalcante, ${ }^{a}$ Rochanne M. Silva, ${ }^{a}$ Paulo N. Bandeira,${ }^{a}$ \\ Hélcio S. dos Santos, ${ }^{a}$ Otília Deusdênia L. Pessoa, ${ }^{b}$ Raimundo Braz-Filho ${ }^{b}$ and \\ Maria Rose Jane R. Albuquerque*,a
}

\author{
${ }^{a}$ Coordenação de Química, Centro de Ciências Exatas e Tecnologia, \\ Universidade Estadual Vale do Acaraú, CP D-3, 62040-340 Sobral-CE, Brazil \\ ${ }^{b}$ Departamento de Química Orgânica e Inorgânica, Universidade Federal do Ceará, \\ 60021-940 Fortaleza-CE, Brazil
}

\begin{abstract}
Dois novos furanoflavonoides, 5-hidróxi-2"-isopropenil-3-metoxifurano-(2",3":7,8)-flavona e 5-hidróxi-2"'-(1-hidróxi-1-metiletil)-3-metoxifurano-(2",3":7,8)-flavona, juntamente com treze compostos conhecidos, foram isolados das cascas das raízes de Lonchocarpus obtusos (Leguminosae). As estruturas de todos os compostos isolados foram determinadas usando métodos espectrométricos tais como RMN 1D e 2D (COSY, HSQC e HMBC) e EMAR, além da comparação com dados espectrais descritos na literatura para compostos de estruturas semelhantes.
\end{abstract}

Two new furanoflavonoids, 5-hydroxy-2"-isopropenyl-3-methoxyfurane-(2",3":7,8)-flavone and 5-hydroxy-2"'-(1-hydroxy-1-methylethyl)-3-methoxyfurane-(2",3":7,8)-flavone, along with thirteen other known compounds, were isolated from the root barks of Lonchocarpus obtusus (Leguminosae). The structures of all compounds were determined by spectrometric methods such as 1D and 2D NMR (COSY, HSQC and HMBC) and HREISMS beside comparison with spectral data for similar compounds.

Keywords: Lonchocarpus obtusos, Leguminosae, furanoflavonoids, flavones

\section{Introduction}

The flavonoids consist of a large group of low-molecular weight phenol compounds whose pharmacological and medicinal properties have been extensively investigated. ${ }^{1,2}$ Several activities have been reported for these compounds, especially as antioxidant, ${ }^{3}$ antiproliferative, ${ }^{4}$ antiinflammatory, ${ }^{5}$ analgesic ${ }^{6}$ and cytotoxic. ${ }^{7}$

The genus Lonchocarpus (Leguminosae, Papilionoideae), comprises approximately 135 species, twenty-four of which are native to Brazil. ${ }^{7}$ Lonchocarpus is known as a prolific source of flavonoids (aurones, chalcones, flavones, flavonols, flavans, flavanones and stilbenes $)^{8}$ has been the subject of incessant investigations searching for compounds of chemical and biological interest. Activities such as gastroprotective, ${ }^{9}$ trypanocidal and antimalarial, ${ }^{10}$ cytotoxic, ${ }^{11}$ anti-inflammatory and antimicrobial ${ }^{12}$ have been reported for compounds isolated from Lonchocarpus.

*e-mail: rjane_7@hotmail.com
As part of an ongoing research for new secondary metabolites from plants of the northeastern Brazil flora we have investigated the extracts of Lonchocarpus obtusus. In the present work the isolation and characterization of two new flavonoids ( $\mathbf{6}$ and 7 ), from the roots of L. obtusos are described. Additionally, thirteen known flavonoids: derriobtusone A (1),${ }^{13}$ obovatin (2), ${ }^{14}$ 3,6-dimethoxy-2", 2"dimethylchromene-(3",4":7,8)-flavone (3), ${ }^{15}$ derriobtusone B (4) ${ }^{13}$ (2",3":7,8)-furanoflavone (5), ${ }^{16}$ pongaglabol $(\mathbf{8})^{17}$ and its methyl ether $(\mathbf{9}),{ }^{17}$ lonchocarpin $(\mathbf{1 0}),{ }^{18}$ 5-hydroxy-2",2"-dimethylchromene-(3",4":6:7)-flavone (11),${ }^{19}$ medicarpin (12), ${ }^{21}$ maackiain $(\mathbf{1 3}),{ }^{22}$ butein $(\mathbf{1 4})^{23}$ and cycloeucalenol $(\mathbf{1 5})^{20}$ were isolated.

\section{Results and Discussion}

Compound 6 was isolated as a yellow resin. Its IR spectrum exhibited absorption bands at 3420 (hydroxyl), 1658 (carbonyl) and $1599 \mathrm{~cm}^{-1}$ (benzene ring) compatible with a flavonoid skeleton. Its HRESIMS spectrum, in the positive mode, revealed a peak at $\mathrm{m} / \mathrm{z} 349.0941$ 


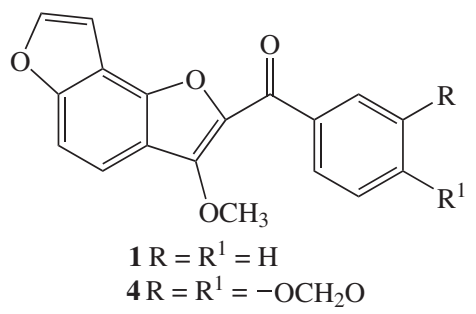<smiles>[R]c1cc2c(cc([R])c3c(=O)c([R])c(-c4ccccc4)oc32)o1</smiles>

$5 \mathrm{R}=\mathrm{R}^{1}=\mathrm{R}^{2}=\mathrm{H}$ $6 \mathrm{R}=\mathrm{C}\left(\mathrm{CH}_{3}\right) \mathrm{CH}_{2}, \mathrm{R}^{1}=\mathrm{OCH}_{3}, \mathrm{R}^{2}=\mathrm{OH}$

$7 \mathrm{R}=\left(\mathrm{CH}_{3}\right)_{2} \mathrm{COH}, \mathrm{R}^{1}=\mathrm{OCH}_{3}, \mathrm{R}^{2}=\mathrm{OH}$

$8 \mathrm{R}=\mathrm{R}^{1}=\mathrm{H}, \mathrm{R}^{2}=\mathrm{OH}$

$9 \mathrm{R}=\mathrm{R}^{1}=\mathrm{H}, \mathrm{R}^{2}=\mathrm{OCH}_{3}$

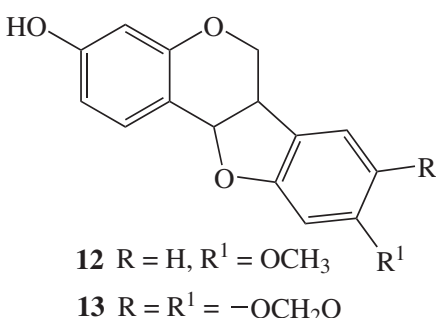

$13 \mathrm{R}=\mathrm{R}^{1}=-\mathrm{OCH}_{2} \mathrm{O}$<smiles>CC1(C)C=Cc2c(cc(O)c3c2OC(c2ccccc2)CC3=O)O1</smiles><smiles>CC1(C)C=Cc2c(ccc(C(=O)/C=C/c3ccccc3)c2O)O1</smiles>

10<smiles>COc1cc2c(=O)c(OC)c(-c3ccccc3)oc2c2c1OC(C)(C)C=C2</smiles><smiles>CC1(C)C=Cc2c(cc3c(c2O)C(=O)CC(c2ccccc2)O3)O1</smiles>

11<smiles>O=C(/C=C/c1ccc(O)c(O)c1)c1ccc(O)cc1O</smiles>

14

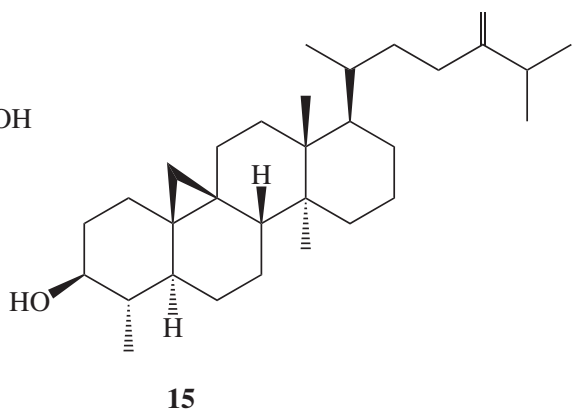

$[\mathrm{M}+\mathrm{H}]^{+}$indicating the molecular formula of $\mathrm{C}_{21} \mathrm{H}_{16} \mathrm{O}_{5}$, corresponding to fourteen degrees of unsaturation. The ${ }^{1} \mathrm{H}$ NMR spectrum showed a signal at $\delta 12.64$ (s) for a chelated hydroxyl group, two multiplets at $\delta 8.14(\mathrm{~m}$, H-2'/H-6') and 7.57 (m, H-3'/H-4'/H-5') appropriate for a monosubstituted benzene ring, two singlets at $\delta 6.88$ (s, H-6) and 6.84 (s, H-3"), and a signal for one methoxyl group at $\delta 3.90$ (3-OMe). In addition, the ${ }^{1} \mathrm{H}$ NMR spectrum showed characteristic signals for an isopropenyl moiety at $\delta 2.15$ (s, 3H-5"), 5.79 (s, H-6a") and 5.21 (s, H-6b"). Apart from the signals typical of a flavonoidic skeleton, the ${ }^{13} \mathrm{C}$ NMR spectrum of $\mathbf{6}$ showed the signals at $\delta 132.3$ (C-4"), 113.8 (C-6") and 19.4 (C-5"), which were inferred to the isopropenyl moiety already suggested by the ${ }^{1} \mathrm{H}$ NMR data. The signals at $\delta 156.8$ (C-2") and 99.5 (C-3"), were associated with a furan ring while a signal at $\delta 60.6$ with the methoxyl group located on $\mathrm{C}$ ring. The NMR spectral data (Table 1) of $\mathbf{6}$ combined with the molecular formula suggested a methoxy-furaneflavone.

In the HMBC spectrum, the correlations of the hydrogens at $\delta 6.84$ (H-3"), 5.79/5.21 (2H-6") and 2.15 (3H-5") with the carbon at $\delta 156.8$ (C-2") were in agreement with the presence of the isopropenyl moiety at C-2", while the long range correlation between the proton signal at $\delta 6.84$ (H-3") with the carbon at $\delta 149.2$ (C-9) confirmed the location of the furan ring at the $\mathrm{C}-7 / \mathrm{C}-8$ position. In order to attend to the feature of a monosubstituted ring $\mathrm{B}$ in the structure of $\mathbf{6}$, the methoxyl group was located in the $\mathrm{C}$ ring at the $\mathrm{C}-3$ position in accordance with the carbon chemical shift at $\delta 140.7$ (C-3) and the correlation between the signal at $\delta 3.90(\mathrm{O}-\mathrm{Me})$ with that carbon. Based on all spectroscopic evidences the structure of $\mathbf{6}$ was established as the 5-hydroxy-2"'-isopropenyl-3-methoxyfurane(2",3":7,8)-flavone.

Compound 7 was also isolated as a yellow resin. Its IR spectrum exhibited absorption bands at 3547 (hydroxyl), 1656 (carbonyl) and 1602 (benzene ring) compatible with the structure of a flavonoid. Its HRESIMS spectrum, in the positive mode, revealed the molecular peak at $\mathrm{m} / \mathrm{z}$ $367.1064[\mathrm{M}+\mathrm{H}]^{+}$indicating the molecular formula of $\mathrm{C}_{21} \mathrm{H}_{18} \mathrm{O}_{6}$, corresponding to thirteen degrees of unsaturation. A detailed analysis of the 1D and 2D NMR spectral data of 7 revealed high structural similarity to flavonoid 6. The main observed difference was related to an isopropyl alcohol moiety supported by the methyl signal at $\delta 1.89$ (s), integrating to 6 hydrogen atoms (3H-5"/3-H-6") and the 
Table 1. ${ }^{1} \mathrm{H}(500 \mathrm{MHz})$ and ${ }^{13} \mathrm{C}(125 \mathrm{MHz})$ NMR spectral data of compounds $\mathbf{6}\left(\mathrm{CDCl}_{3}\right)$ and $7\left(\mathrm{C}_{5} \mathrm{D}_{5} \mathrm{~N}\right)$

\begin{tabular}{|c|c|c|c|c|}
\hline \multirow[b]{2}{*}{ C } & \multicolumn{2}{|c|}{6} & \multicolumn{2}{|c|}{7} \\
\hline & $\delta_{\mathrm{C}}$ & $\delta_{\mathrm{H}}$ & $\delta_{\mathrm{C}}$ & $\delta_{\mathrm{H}}$ \\
\hline 2 & 155.9 & - & 156.8 & - \\
\hline 3 & 140.7 & - & 141.0 & - \\
\hline 4 & 180.0 & - & 180.6 & - \\
\hline 5 & 159.2 & - & 159.1 & - \\
\hline 6 & 95.1 & $6.88(\mathrm{~s})$ & 95.7 & $7.20(\mathrm{~s})$ \\
\hline 7 & 159.5 & - & 159.9 & - \\
\hline 8 & 110.4 & - & 117.0 & - \\
\hline 9 & 149.2 & - & 149.0 & - \\
\hline 10 & 108.3 & - & 108.8 & - \\
\hline 1 ' & 130.8 & - & 131.4 & - \\
\hline 2 ' & 128.6 & $8.14(\mathrm{~m})$ & 129.4 & $8.27(\mathrm{~m})$ \\
\hline 3 ' & 129.4 & $7.57(\mathrm{~m})$ & 129.7 & $7.58(\mathrm{~m})$ \\
\hline $4^{\prime}$ & 131.3 & 7.57 (m) & 131.9 & $7.58(\mathrm{~m})$ \\
\hline 5 , & 129.4 & 7.57 (m) & 129.7 & $7.58(\mathrm{~m})$ \\
\hline 6 ' & 128.6 & $8.14(\mathrm{~m})$ & 129.4 & $8.27(\mathrm{~m})$ \\
\hline $2 "$ & 156.8 & - & 166.0 & - \\
\hline $3 "$ & 99.5 & $6.84(\mathrm{~s})$ & 98.2 & $7.29(\mathrm{~s})$ \\
\hline $4 "$ & 132.3 & - & 68.9 & - \\
\hline $6 "$ & 113.8 & $\begin{array}{l}5.79(\mathrm{~s}) \\
5.21(\mathrm{~s})\end{array}$ & 30.0 & 1.89 (s) \\
\hline $5 "$ & 19.4 & $2.15(\mathrm{~s})$ & 30.0 & $1.89(\mathrm{~s})$ \\
\hline $\mathrm{MeO}-3$ & 60.6 & $3.90(\mathrm{~s})$ & 60.8 & $3.96(\mathrm{~s})$ \\
\hline HO-5 & - & $12.64(\mathrm{~s})$ & - & $13.2(\mathrm{~s})$ \\
\hline
\end{tabular}

Chemical shifts $(\delta)$ in ppm. Deuterated solvent $(0.6 \mathrm{~mL})$.

carbon signals at $\delta 30.0$ (C-5" and C-6") and $\delta 68.9$ (C-4") (Table 1). The isopropyl alcohol moiety was positioned at C-2" through the HMBC correlations between the methyl signal at 1.89 (3H-5"/3-H-6") and the carbon signal at 166.0 (C-2"), in accordance with the hydration of the propenyl side chain of $\mathbf{6}$. Additional long range correlations can be seen in Figure 1. Based on the aforementioned data the

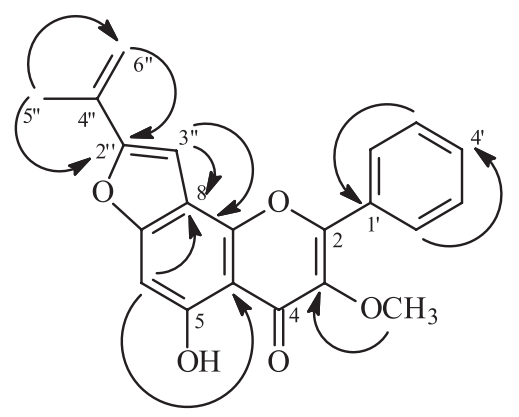

6 structure of 7 was established as 5-hydroxy-2"-(1-hydroxy1-methylethyl)-3-methoxyfurane-(2",3":7,8)-flavone, a new hydrated derivative of flavone $\mathbf{6}$.

Previous phytochemicals studies have demonstrated that Lonchocarpus is a prolific source of flavonoids with furan or pyran substituent at ring $\mathrm{A}$ in an angular or linear position. Flavonoids 6 and 7 were previously unknown, while $\mathbf{8 , 9}$ and $\mathbf{1 4}$ are been reported for the first time in this genus.

\section{Experimental}

\section{General experimental procedures}

Melting points were measured on a digital Mettler Toledo FP90 apparatus and are uncorrected. IR spectra were recorded using a Perkin-Elmer FT-IR 1000 spectrometer. Electrospray ionization-high resolution mass spectra were run on a quadrupole LCMS-IT-TOF (Shimadzu) spectrometer equipped with an electrospray ionization source. 1D and 2D NMR experiments were performed on a Bruker Avance DRX-500 spectrometer $\left({ }^{1} \mathrm{H} 500 \mathrm{MHz}\right.$, ${ }^{13} \mathrm{C} 125 \mathrm{MHz}$ ) equipped with a $5 \mathrm{~mm}$ inverse detection Z-gradient probe. ${ }^{1} \mathrm{H}$ and ${ }^{13} \mathrm{C}$ NMR spectra were measured at $27^{\circ} \mathrm{C}$ using $\mathrm{CDCl}_{3}$ and pyridine as the solvent $(0.6 \mathrm{~mL})$. Open column chromatography was run using silica gel 60 (70-230 mesh, Vetec), while flash column chromatography was run on silica gel (230-400 mesh, Merck). TLC was performed on precoated silica gel polyester sheets (Kieselgel $60 \mathrm{~F}_{254}, 0.20 \mathrm{~mm}$, Merck) by detection with a spraying reagent (vanillin/perchloric acid/EtOH solution) followed by heating at $100{ }^{\circ} \mathrm{C}$.

\section{Plant material}

The roots of Lonchocarpus obtusus were collected, in April 2007, from Meruoca County (Ceará State, Brazil). The plant authentication was performed by Professor Afrânio Gomes Fernandes and a voucher specimen

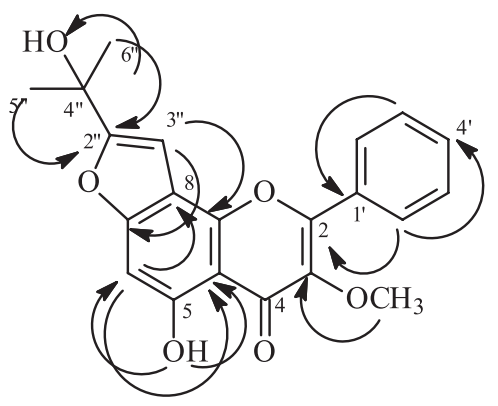

7

Figure 1. Key HMBC correlations for compounds 6 and 7. 
(No. 39550) has been deposited at the Herbário Prisco Bezerra (EAC) of the Departamento de Biologia, Universidade Federal do Ceará.

\section{Extraction and isolation}

Dried roots bark (720 g) and wood (750 g) of L. obtusus were separately, powdered and then extracted at room temperature with $n$-hexane $(3 \times 2.0 \mathrm{~L})$ followed by ethanol $(3 \times 2.0 \mathrm{~L})$. The solvents were distillated under reduced pressure to afford the crude $n$-hexane (root bark: $37.9 \mathrm{~g}$; root wood: $56.1 \mathrm{~g}$ ) and EtOH (root bark: $3.9 \mathrm{~g}$; root wood: $20.5 \mathrm{~g}$ ) extracts. During the distillation process of the $n$-hexane extract of the root bark was observed a yellowish precipitate which was filtrated and purified by crystallization in acetone to give $\mathbf{1}(21.3 \mathrm{mg})$. The $n$-hexane extract from the root bark $(36.0 \mathrm{~g})$ was subjected to silica gel column chromatography ( $36.6 \mathrm{~g}$ ) by elution with $n$-hexane $(800 \mathrm{~mL})$, EtOAc $(200 \mathrm{~mL}), \mathrm{CHCl}_{3}(500 \mathrm{~mL})$ and $\mathrm{MeOH}$ $(100 \mathrm{~mL})$, yielding the following fractions, after solvent evaporation: $n$-hexane $(9.8 \mathrm{~g}), \mathrm{CHCl}_{3}(23.0 \mathrm{~g})$, EtOAc $(643.0 \mathrm{mg})$ and $\mathrm{MeOH}(812.0 \mathrm{mg})$. The $n$-hexane fraction $(9.8 \mathrm{~g})$ was chomatographed over silica gel, eluting with $n$-hexane, $n$-hexane/EtOAc $(9: 1,8: 2,7: 3,6: 4,1: 1)$ and EtOAc to afford 7 fractions of $100 \mathrm{~mL}$ each $\left(\mathrm{F}_{\mathrm{A}} 1-\mathrm{F}_{\mathrm{A}} 7\right) . \mathrm{F}_{\mathrm{A}} 3$ (796.3 mg, $n$-hexane/EtOAc 8:2 mixture) was subjected to a silica gel flash column chromatography using $n$-hexane/ EtOAc 9:1 mixture to yield 2 $(5.6 \mathrm{mg})$.

The $\mathrm{CHCl}_{3}$ fraction $(23.0 \mathrm{~g})$ was chromatographed over silica gel $(81.3 \mathrm{~g})$, eluting with $n$-hexane/ $\mathrm{CHCl}_{3}(6: 4,4: 6$, 2:8), $\mathrm{CHCl}_{3}, \mathrm{EtOAc}$ and $\mathrm{MeOH}$ to afford 6 fractions of $200 \mathrm{~mL}$ each $\left(\mathrm{F}_{\mathrm{B}} 1-\mathrm{F}_{\mathrm{B}} 6\right) . \mathrm{F}_{\mathrm{B}} 5(7.1 \mathrm{~g}$, EtOAc) was subjected to silica gel column chromatography using $n$-hexane/ $\mathrm{CHCl}_{3}$ (1:1, 2.5:7.5), $\mathrm{CHCl}_{3}, \mathrm{CHCl}_{3} / \mathrm{EtOAc}$ (9:1, 8:2, 7:3), EtOAc and $\mathrm{MeOH}$, to afford 9 fractions of $125 \mathrm{~mL}$ each $\left(\mathrm{F}_{\mathrm{C}} 1-\mathrm{F}_{\mathrm{C}} 9\right)$. $\mathrm{F}_{\mathrm{C}} 1\left(3.0 \mathrm{~g}, n\right.$-hexane/ $\left.\mathrm{CHCl}_{3} 1: 1\right)$ was chromatographed over a silica gel column, using $n$-hexane with increasing amounts of $\mathrm{CHCl}_{3}$ (9:1 to 1:9) as eluent to yield 102 fractions $(10 \mathrm{~mL}$ each), that after TLC analysis yielded 9 fractions $\left(\mathrm{F}_{\mathrm{D}} 1-\mathrm{F}_{\mathrm{D}} 9\right)$. $\mathrm{F}_{\mathrm{D}} 4$ (1.4 g, $n$-hexane/ $\mathrm{CHCl}_{3} 1: 1$ and 4:6) was subjected to silica gel column chromatography using $n$-hexane/EtOAc gradient (9.5:0.5 to 0.5:9.5), EtOAc and $\mathrm{MeOH}$ to give 115 fractions, which after TLC analysis were combined into 7 fractions $\left(\mathrm{F}_{\mathrm{E}} 1-\mathrm{F}_{\mathrm{E}} 7\right) . \mathrm{F}_{\mathrm{E}} 4(60.6 \mathrm{mg}, n$-hexane/EtOAc 9.5:0.5 to 8:2) was rechromatographed using the same solvent system to afford $\mathbf{3}(34.1 \mathrm{mg})$ and $\mathbf{4}(16.4 \mathrm{mg}) . \mathrm{F}_{\mathrm{C}} 2$ (2.1 g, $n$-hexane/ $\mathrm{CHCl}_{3}$ 2.5:7.5) was subjected to silica gel column chromatography using $n$-hexane/EtOAc gradient (8:2, 7.5:2.5, 7:3) EtOAc, and MeOH. Fractions $n$-hexane/ EtOAc 8:2 and 7.5:2.5 (364 mg) were combined and subjected to repeated silica gel column chromatography using $n$-hexane/EtOAC gradient to yield $\mathbf{5}(24.3 \mathrm{mg}) . \mathrm{F}_{\mathrm{C}} 3$ $\left(1.1 \mathrm{~g}, \mathrm{CHCl}_{3}\right)$ was chromatographed over a silica gel column, eluting with $n$-hexane/EtOAc gradient (8:2 to 2:8), EtOAc and $\mathrm{MeOH}$, to give 119 fractions which after TLC analysis were combined into eight fractions $\left(\mathrm{F}_{\mathrm{F}} 1-\mathrm{F}_{\mathrm{F}} 8\right) . \mathrm{F}_{\mathrm{F}} 3$ (98.4 mg, $n$-hexane/EtOAc 8:2) was subjected to successive purifications using Sephadex LH-20 $\left(\mathrm{CH}_{2} \mathrm{Cl}_{2} / \mathrm{MeOH} 1: 1\right)$ to yield $6(6.5 \mathrm{mg})$ and $7(3.0 \mathrm{mg})$. Chromatography of subfraction $\mathrm{F}_{\mathrm{F}} 7$ (142.5 mg, EtOAc) over silica gel eluting with $\mathrm{CHCl}_{3}$ yielded $8(52.6 \mathrm{mg})$. The EtOH extract from the root bark $(76.1 \mathrm{~g})$ was subjected to silica gel column chromatography eluting with $\mathrm{CH}_{2} \mathrm{Cl}_{2}, \mathrm{CH}_{2} \mathrm{Cl}_{2}$ /EtOAc (7.5:2.5, 1:1), EtOAc, EtOAc/MeOH (7.5:2.5) and $\mathrm{MeOH}$ (1000 $\mathrm{mL}$ of the each solvent), to afford the following fractions: $\mathrm{CH}_{2} \mathrm{Cl}_{2} \mathrm{I}(2.0 \mathrm{~g}), \mathrm{CH}_{2} \mathrm{Cl}_{2}$ II $(8.8 \mathrm{~g}), \mathrm{CH}_{2} \mathrm{Cl}_{2} /$ EtOAc 7.5:2.5 (12.7 g), $\mathrm{CH}_{2} \mathrm{Cl}_{2} / \mathrm{EtOAc} 1: 1$ (4.2 g), EtOAc (2.6 g), EtOAc/MeOH 7.5:2.5 (9.5 g) and $\mathrm{MeOH}(7.7 \mathrm{~g})$. $\mathrm{CH}_{2} \mathrm{Cl}_{2} \mathrm{I}$ fraction $(2.0 \mathrm{~g})$ was subjected to repeated silica gel flash column chromatography using $n$-hexane $/ \mathrm{CH}_{2} \mathrm{Cl}_{2}$ 9:1 to afford compounds $\mathbf{9}(10.7 \mathrm{mg})$ and $\mathbf{1 0}(12.3 \mathrm{mg})$. The $n$-hexane extract from the root wood ( $3.9 \mathrm{~g}$ ) was subjected to silica gel column chromatography eluting with $n$-hexane $(920 \mathrm{~mL}), \mathrm{EtOAc}(150 \mathrm{~mL}), \mathrm{CHCl}_{3}(450 \mathrm{~mL})$ and $\mathrm{MeOH}$ $(100 \mathrm{~mL})$ to yield the fractions: $n$-hexane $(0.8 \mathrm{~g}), \mathrm{CHCl}_{3}$ $(2.5 \mathrm{~g}), \mathrm{EtOAc}(0.3 \mathrm{~g})$ and $\mathrm{MeOH}(0.02 \mathrm{~g}) . \mathrm{CHCl}_{3}$ fraction $(2.5 \mathrm{~g})$ was fractioned over silica gel, eluting with $n$-hexane/ EtOAc (9:1, 8:2, 7:3, 6:4, 1:1, 7.5:2.5), EtOAc and $\mathrm{MeOH}$, to afford 100 fractions ( $10 \mathrm{~mL}$ each) which after TLC analysis were combined to 10 fractions $\left(\mathrm{F}_{\mathrm{G}} 1-\mathrm{F}_{\mathrm{G}} 10\right)$. Fraction $\mathrm{F}_{\mathrm{G}} 3$ (0.6 g, $n$-hexane/EtOAc 9:1 and 8:2) was subjected to successive silica gel column chromatography to yield compounds $\mathbf{1}(12.0 \mathrm{mg}), \mathbf{5}(6.2 \mathrm{mg})$ and $\mathbf{1 1}$ $(7.2 \mathrm{mg})$. The EtOH extract from the root wood $(15.9 \mathrm{~g})$ was subjected to silica gel column chromatography eluted with $\mathrm{CH}_{2} \mathrm{Cl}_{2}(500 \mathrm{~mL}), \mathrm{CH}_{2} \mathrm{Cl}_{2} /$ EtOAc 1:1 $(850 \mathrm{~mL})$, EtOAc $(600 \mathrm{~mL}), \mathrm{EtOAc} / \mathrm{MeOH} 1: 1(600 \mathrm{~mL})$ and $\mathrm{MeOH}$ (800 mL), yielding the respective fractions: $\mathrm{CH}_{2} \mathrm{Cl}_{2}(2.9 \mathrm{~g})$, $\mathrm{CH}_{2} \mathrm{Cl}_{2} / \mathrm{EtOAc} 1: 1$ (4.0 g), EtOAc (1.6 g), EtOAc/MeOH 1:1 $(6.2 \mathrm{~g})$ and $\mathrm{MeOH}(1.3 \mathrm{~g})$. The $\mathrm{CH}_{2} \mathrm{Cl}_{2}$ fraction $(2.9 \mathrm{~g})$ was subjected to silica gel column chromatography using $n$-hexane/EtOAc gradient (95:0.5 to 1:1, 2.5:7.5), EtOAc and $\mathrm{MeOH}$ to give 103 fractions $(10 \mathrm{~mL})$ that after TLC analysis were pooled into 16 fractions $\left(\mathrm{F}_{\mathrm{H}} 1-\mathrm{F}_{\mathrm{H}} 16\right)$. Fraction $\mathrm{F}_{\mathrm{H}} 7$ (261.1 mg, $n$-hexane/EtOAc 8:2 and 7.5:2.5) yielded the mixture of compounds $\mathbf{1 2} / \mathbf{1 3}(21.6 \mathrm{mg})$ and $\mathbf{3}(5.3 \mathrm{mg})$. Fraction $\mathrm{CH}_{2} \mathrm{Cl}_{2} \mathrm{III}(0.7 \mathrm{~g})$ was subjected to slica gel column chromatography using $n$-hexane/EtOAc (9:1, 8.5:1.5, 8:2, 7.5:2.5, 7:3, 4:6), EtOAc and $\mathrm{MeOH}$ resulting in 16 fractions $\left(\mathrm{F}_{\mathrm{I}} 1-\mathrm{F}_{\mathrm{I}} 16\right)$, after TLC analysis. $\mathrm{F}_{\mathrm{I}} 5$ ( $n$-hexane/ EtOAc 8:2, $130.5 \mathrm{mg}$ ) was fractionated on Sephadex LH-20 column using acetone/MeOH 1:1 to produce the mixture 
of 13/14 (6.6 mg). Fraction $\mathrm{CH}_{2} \mathrm{Cl}_{2} / \mathrm{EtOAc} \mathrm{I} \mathrm{(3.0} \mathrm{g)} \mathrm{was}$ chromatographed over silica gel, eluting with $n$-hexane/ EtOAc (9:1, 8:2, 7:3, 1:1, 4:6), EtOAc and $\mathrm{MeOH}$ to afford 7 fractions (F1-F7, $100 \mathrm{~mL}$ each). F6 ( $n$-hexane/EtOAc 1:1, $258.3 \mathrm{mg})$ after purification over Sephadex $\mathrm{LH}-20\left(\mathrm{CH}_{2} \mathrm{Cl}_{2} /\right.$ $\mathrm{MeOH} 1: 9)$ yielded 15 (3.5 mg).

\section{Supplementary Information}

Supplementary data for compounds $\mathbf{6}$ and $\mathbf{7}$ are available free of charge at http://jbcs.sbq.org.br as PDF file.

\section{Acknowledgments}

The authors thank to Prof. Edilberto R. Silveira (UFC) for the plant material collection and for the providing the NMR facilities, and to CNPq/CAPES/FUNCAP and PRONEX for the financial support.

\section{References}

1. Paul, M. D.; Medicinal Natural Products: A Biosyntthetic Approach, $2^{\text {nd }}$ ed., John Wiley \& Sons: New York, 2003.

2. Lim, C.-G.; Koffas, M. A. G.; Curr. Org. Chem. 2010, 14, 1727.

3. Ferreira, J. F. S.; Luthria, D. L.; Sasaki, T.; Heyerick, A.; Molecules 2010, 15, 3135.

4. Magalhães, A. F.; Tozzi. A. M. G. A.; Magalhães, E. G.; Sannomiya, M.; Soriano, M. D. P. C.; Perez, M. A. F.; An. Acad. Bras. Cienc. 2007, 79, 351.

5. Garcia-Lafuente, A.; Guillamon, E.; Villares, A.; Rostagno, M.A.; Martinez, J. A.; Inflammation Res. 2009, 58, 537.

6. Parveen, Z.; Deng, Y.; Saeed, M. K.; Dai, R.; Ahamad, W.; Yu, Y. H.; YaKugaku Zasshi 2007, 127, 1275.

7. Patel, B.; Das, S.; Prakash, R.; Yasir, M.; Int. J. Adv. Pharm. Sci. 2010, 1, 32 .
8. Lima, A. F.; Mileo, P. G.; Andrade-Neto, M.; Braz-Filho, R.; Silveira, E. R.; Pessoa, O. D. L.; Magn. Reson. Chem. 2009, 47, 165 .

9. Campos, D. A.; de Lima, A. F.; Ribeiro, S. R. L.; Silveira, E. R.; Pessoa, O. D. L.; Rao, V. S.; Santos, F. A.; J. Pharm. Pharmacol. 2008, 60, 391.

10. Santos, D. A. P.; Braga, P. A. C; da Silva, M. F. D. F.; Fernandes, J. B.; Vieira, P. C.; Magalhaes, A. F.; Magalhaes, E. G.; Marsaioli, A. J.; Moraes, V. R. S; Rattray, L.; Croft, S. L.; J. Pharm. Pharmacol. 2009, 61, 257.

11. Cassidy, C. E.; Setzer, W. N.; J. Mol. Model. 2010, 16, 311.

12. Alencar, N. M. N.; Cavalcante, C. F.; Vasconcelos. M. P.; Leite, K. B.; Aragao, K. S.; Assreuy, A. M. S.; Nogueira, N. A.P.; Cavada, B. S.; Vale, M. R.; J. Pharm. Pharmacol. 2005, 57, 919.

13. Nascimento, M. C.; Dias, R. L. V.; Mors, W. B.; Phytochemistry 1976, 15, 1553.

14. Andrei, C. C.; Ferreira, D. T.; Faccione, M.; Moraes, L. A. B.; Carvalho, M. G.; Braz-Filho, R.; Phytochemistry 2000, 55, 799.

15. Arriaga, A. M. C.; Gomes, G. A.; Braz-Filho, R.; Fitoterapia 2000, 71, 211.

16. Garcez, F. R.; Scramin, S.; Nascimento, M. C.; Mors, W. B.; Phytochemistry 1988, 27, 1079.

17. Talapatra, S. K.; Mallik, A. K.; Talapatra, B.; Phytochemistry 1980, 19, 1199.

18. Monache, F. D.; Suarez, L. E. C.; Marini-Bettolo, G. B.; Phytochemistry 1978, 17, 1812.

19. Borges-Argáez, R.; Díaz, M. E. P.; Waterman, P. G.; PeñaRodríguez, L. M.; J. Braz. Chem. Soc. 2005, 16, 1078.

20. Paula, J. R.; Vieira, I. J. C.; Silva, M. F. G. S., Fo, E. R.; Fernandes, J. B.; Vieira, P. C.; Pinheiro, A. L.; Vilela, E. F.; Phytochemistry 1997, 44, 1449.

Submitted: June 26, 2011

Published online: December 6, 2011 